\title{
Penerapan Model Pembelajaran IPA Dengan Menggunakan Metode Keterampilan Berfikir Kreatif Siswa Dan Pemahaman Konsep IPA Siswa SMP
}

\author{
Silvia Bella Yolanda ${ }^{1^{*}}$ \\ ${ }^{1)}$ Pendidikan IPA/ Jurusan Pendidikan MIPA, FKIP, Universitas Jember , Indonesia \\ Mahasiswa Pendidikan IPA/ Pendidikan MIPA, FKIP, Universitas Jember 68121 \\ Email : silviabella922@gmail.com
}

\begin{abstract}
Abstrak: Kurang terlibatnya seorang peserta didik dalam suatu proses pembelajaran atau dalam kata lain yang bersifat eacher center, hal tersebuat dapat menyebabkan seorang anak didik atau ppeserta didik mengalami rendahnya daya untuk berpikir kreatif, baik dari segi intelektual, konsentrasi, percaya diri dan kepribadian. Serta didalam suatu proses pembelajaran terdapat masalah mengenai kurangnya atau rendahnya pemahaman siswa terhadap konsep mata pelajaran IPA. Penelitian ini dibuat guna untuk meningkatkan penerapan model dalam pembelajaran IPA siswa SMP yang menggunakan metode keterampilan berfikir kreatif siswa dan pemahaman konsep IPA, serta melihat bahwa disekolah sudah menerapkan model pembelajaran terseburt atau belum. Dalam penelitian ini menggunakan metode analisis deskriptif dengan pengambilan data melalui proses wawancara tes mengenai materi pembelajaran dengan beberapa siswa SMP kelas IX. Sampel penelitian ini diambil dari SMP Negeri 3 Rambipuji dengan menggunakan 25 siswa. Dari hasil penelitian yang telah dilakukan melalui tes wawancara dapat dinyatakan bahwasanya 70\% dari siswa SMP Negeri 3 Rambipuji sudah menjawab dengan baik dan dalam hal berfikir kreatif dan pemahaman konsepnya sudah baik. Sehingga dapat dinyatakan bahwasanya penerapan model pembelajaran IPA dengan menggunakan metode berfikir kreatif dan metode pemahaman konsep sangat penting dan berpengaruh dalam kegiatan pembelajaran.
\end{abstract}

Kata kunci: Keterampilan Berfikir Kreatif Siswa, Pemahaman Konsep IPA

Abstract: The lack of involvement of a student in a learning process or in other words that is eacher center, it can cause a student or student to experience low power to think creatively, both in terms of intellectual, concentration, confidence and personality. As well as in a learning process there is a problem regarding the lack or lack of students' understanding of the concept of science subjects. This research was made in order to improve the application of models in science learning for junior high school students who use students' creative thinking skills and understanding the science concept, and see that schools have implemented the learning model or not. In this study using descriptive analysis method with data retrieval through a test interview process about learning materials with some junior high school students of class IX. The sample of this study was taken from Public Middle School 3 Rambipuji using 25 students. From the results of research that has been done through interview tests it can be stated that $70 \%$ of students of SMP Negeri 3 Rambipuji have answered well and in terms of creative thinking and understanding the concept is good. So that it can be stated that the application of the science learning model by using creative thinking methods and methods of understanding concepts is very important and influential in learning activities.

Keywords: Students' Creative Thinking Skills, Understanding the Science Concept

\section{PENDAHULUAN}

Kemampuan berpikir kreatif merupakan salah satu kemampuan siswa yang harus dikembangkan dalam proses pembelajaran. Sesuai dengan Pasal 2 Undang-Undang Nomor 20 Tahun 2003 tentang Sistem Pendidikan Nasional dalam pasal 3 bahwa pendidikan nasional berfungsi mengembangkan kemampuan dan membentuk watak serta peradaban bangsa yang bermartabat dalam rangka mencerdaskan kehidupan bangsa, bertujuan untuk mengembangkan potensi peserta didik agar menjadi manusia yang beriman dan bertakwa kepada Tuhan Yang Maha Esa, berakhlak mulia, sehat, berilmu, cakap, kreatif, mandiri, dan menjadi warga negara yang demokratis serta bertanggung jawab (Depdiknas, 2006:105). 
Peranan guru sangat penting dalam menumbuhkan berpikir kreatif siswa pada pembelajaran matematika. Siswa yang memiliki kemampuan berpikir kreatif dapat berpikir lancar (fluency) yaitu memunculkan banyak ide dan jawaban dalam menyelesaikan masalah; berpikir luwes (flexibility) yaitu meliputi menghasilkan jawaban yang bervariasi; berpikir orisinal (originality) yaitu mampu melahirkan jawaban yang unik serta dapat memikirkan cara yang tak lazim; berpikir elaborasi (elaboration) yaitu mengembangkan suatu gagasan dengan menambah atau merinci suatu gagasan (Munandar, 2009: 34).

Memiliki kemampuan berpikir kreatif sangat penting dan bermanfaat sekali bagi peserta didik, terutama untuk mereka memecahkan suatu masalah atau kesulitan dalam hal belajar. Kemampuan berpikir kreatif siswa dengan baik, akan dapat menentukan kesuksesan dalam belajar. Dalam memahami suatu kondisi dan situasi yang diperlukan untuk mengembangkan berpikir kreatif. Guru dapat mendorong dan memelihara perkembangan serta merealisasikan bakat kreatif dari siswa. Seorang guru dapat dikatakan profesionalapabila guru tersebut mampu mengelola kelas agar siswa dapat berpikir kreatif, salah satunya adalah memilih metode pembelajaran yang tepat digunakan dalam mengembangkan daya kreatif siswa itu sendiri (Hendriana, 2014: 54).

Kreativitas merupakan suatu kemampuan untuk menghasilkan sesuatu yang baru atau ide-ide baru dalam menghadapi suatu masalah. Sadar akan pentingnya kreativitas dalam menyelesaikan permasalahan sehari-hari, guru diharapkan dapat merancang metode pembelajaran maupun pendekatanpendekatan yang dapat mengembangkan kreativitas siswa, namun sebelum itu guru terlebih dahulu harus mengetahui sejauh mana kreativitas yang dimiliki siswa dengan meminta siswa untuk menyelesaikan permasalahan yang tidak hanya fokus pada satu solusi tapi juga beberapa solusi. Oleh karena itu penting sekali untuk mengukur bagaimana kemampuan berpikir kreatif yang dimiliki siswa terutama kemampuan berpikir kreatif di setiap aspeknya, agar guru dapat mengenal potensi setiap siswanya dan dapat menentukan metode yang tepat untuk mengembangkan kemampuan berpikir kreatif siswa secara seimbang disetiap aspeknya (Salim, 2014: 43).

Berpikir kreatif memiliki keterkaitan dengan pemecahan masalah. Keterkaitan itu dapat dilihat dari pendapat Mahmudi (2008) yang menyatakan bahwa keterampilan berpikir kreatif memungkinkan seorang individu memandang suatu masalah dari berbagai perspektif sehingga memungkinkannya untuk menemukan solusi kreatif dari masalah yang akan diselesaikan.

Penguasaan

konsep adalahkemampuan siswa dalam memahami konsep-konsep setelah kegiatan pembelajaran. Penguasaan konsep dapat diartikan sebagai kemampuan siswa dalam memahami makna secara ilmiah baik teori maupun penerapannya dalam kehidupan sehari-hari (Dahar, 2006: 4). Sedangkan definisi penguasaan konsep yang lebih komprehensif dikemukakan oleh Bloom yaitu kemampuan menangkap pengertianpengertian seperti mampu mengungkapkan suatu materi yang disajikan ke dalam bentuk yang lebih dipahami, mampu memberikan interpretasi dan mampu mengaplikasikannya.

Pembelajaran IPA terpadu apabila dilakukan dengan benar sesuai dengan prosedur yang ada maka akan memberikan peluang bagi perkembangan dalam prosespembelajaran IPA. Suatu pembelajaran yang bermakna dikonstruksi oleh siswa melalui pengalaman dalam lingkungannya. Pembelajaran IPA diperlukan sebuah penelitian guna mengetahui penerapan model pembelajaran IPA untuk menunjang keberhasilan proses pembelajarannya khususnya meningkatkan pemahaman konsep IPA dan pemahamanpemahaman keterampilan kreatif siswa (Toharudin, 2016: 25).

Pada pembelajaran IPA, seorang guru dituntut agar dapat mengembangkan serta memupuk perkembangan Kreatif 
siswa dan rasa ingin tahu, kesadaran tentang adanya hubungan saling mempengaruhi antara IPA dengan lingkungan, dan dapat menerapkan keterampilan dari proses untuk menyelidiki alam dan sekitarnya pada diri siswa. Dalam pembelajaran IPA peserta didik harus dibiasakan untuk melakukan suatu eksperimen, observasi, pengumpulan data, menguji konsep dan menarik suatu kesimpulan. Siswa diberi kesempatan untuk menyusun sendiri konsep-konsepnya, selanjutnya dapat diaplikasikan dalam kehidupannya (Rismawati, 2010: 201).

Menurut Djamarah (1995: 22) menyatakan bahwa "dengan metode eksperimen merupakan salah satu cara penyajian pelajaran dimana siswa akan melakukan percobaan dengan membuktikan sendiri mengenai sesuatu yang telah ia dipelajari". Implementasi dari adanya metode eksperimen ini akan sangat membantu peserta didik dalam melangsungkan proses belajar mereka. Karena dengan menggunakan metode ini peserta didik akan diberikan kesempatan untuk mengalami dan melihat sendiri atau melakukan sendiri, mengikuti proses, serta bmengamati suatu objek, kemudian menganalisis, lalu membuktikan, dan menarik kesimpulan sendiri mengenai suatu objek yang telah ia lakukan atau amati, pada keadaan atau proses tertentu. Maka dari itu, siswa dituntut untuk mengalami sendiri, mencoba sendiri, membuktikan sendiri, mencari kebenaran atau mencoba mencari suatu teori danmenarik kesimpulan dari proses yang dialaminya.

Peran guru sangat peting dalam mengajarkan konsep-konsep IPA ke siswa. Suatu pembelajaran IPA menjadi salah satu upaya untuk proses membelajarkan siswa agar memahami hakikat mengenai materi IPA sebagai proses, produk, aplikasi, dan sikap (Mariana, 2009). Metode pembelajaran Teacher center menyebabkan siswa menjadi kurang mampu untuk menggali segala fenomena alam yang terjadi dilingkungan sekitar kita sehingga hal tersebut dapat membuat kemampuannya untuk menunjang atau mengasah pemahaman konsepnya menjadi kurang (Saputra, 2012: 38).

Dalam suatu suasana belajar dan pembelajaran belum maksimalnya proses pembelajaran yang dilakukan sebagai upaya untuk menguatkan pemahaman mengenai konsep-konsep IPA yang dipelajari, misalnya kegiatan praktikum atau percobaan mengamati sesuatu masih kurang. Hal tersebut merupakan salah salah satu yang menyebabkan siswa kesulitan untuk memahami konsep-konsep IPA (Rizal, 2014: 160).

\section{METODE PENELITIAN}

Metode yang digunakan dalam artikel ilmiah penelitian ini yaitu metode analisis deskriptif dengan teknik pengambilan data melalui proses wawancara dan Jenis instrument pengumpulan data yang digunakan dalam penelitian ini adalah tes wawancara berupa pertanyaan materi IPA mengenai pertumbuhan dari perkecambahan (kacang hijau) guna mengetahui metode berfikir kreatif siswa serta pemahaman konsep dengan beberapa siswa SMP kelas IX. Sampel penelitian ini diambil dari SMP Negeri 3 Rambipuji dengan menggunakan 25 siswa. Penelitian menggunakan tes wawancara yang dilakukakan yakni menanyakan hal yang mana siswa dapat beripikir dan menjawab secara benar, dengan tujuan dapat melihat bagaimana siswa tersebut dapat menjawab dengan pikiran yang kreatif serta melihat seberapa jauh pemahaman siswa tersebut. Soal tersebut meliputi kategori mengingat, memahami, menerapkan, menganalisis dan mengevaluasi. Kemudian data yang diperoleh akan dianalisis dan disimpulkan.

\section{HASIL DAN PEMBAHASAN}

Dari hasil penelitian ini didapatkan data yang diambil dari tes wawancara. Dari hasil wawancara dengan 25 siswa SMP kelas IX, yakni wawancara yang dilakukan dengan menanyakan materi IPA yaitu tentang pertumbuhan dari kacang hijau. Dimana hal ini bertujuan untuk mengetahui seberapa besar pengetahuan siswa tersebut 
dalam memahami konsep serta cara penyelesaainnya dengan metode berfikir kreatifnya dari para siswa tersebut. Dari tes wawancara yang telah dilakukan dari 25 siswa terdapat 19 siswa yang dapat menjawab pertanyaan atau tes wawancara dengan baik dan benar. Dan 6 siswa lainnya belum dapat menjawab tes dengan benar. Berikut merupakan tabel data dari tes yang telah dilakukan:

Tabel 1. Jawaban Tes Wawancara Melihat Kemampuan Berfikir Kreatif Siswa :

\begin{tabular}{|c|l|c|}
\hline Jumlah siswa & Kemampuan Berfikir Kreatif Siswa & kriteria \\
\hline 19 & $\begin{array}{l}\text { Siswa dapat menyelesaikan } \\
\text { masalah dengan bermacam-macam } \\
\text { solusi dan jawaban } \\
\text { Kefasihan Siswa dapat } \\
\text { memecahkan masalah dalam satu cara, } \\
\text { kemudian dengan menggunakan cara } \\
\text { lain }\end{array}$ & \\
\hline 6 & $\begin{array}{l}\text { Siswa belum dapat menyelesaikan } \\
\text { masalah dengan tidak dapat menjawab } \\
\text { pertanyaan yang diberikan }\end{array}$ & Kurang kreatif \\
\hline
\end{tabular}

Tabel 2. Jawaban Tes Wawancara Melihat Kemampuan Pemahaman Konsep :

\begin{tabular}{|c|l|c|}
\hline Jumlah siswa & kemampuan pemahaman konsep & kriteria \\
\hline 19 & $\begin{array}{l}\text { Siswa sudah memahami konsep } \\
\text { dengan dapat menjawab pertanyaan } \\
\text { yang diberikan dengan baik dan benar. }\end{array}$ & Baik \\
\hline 6 & $\begin{array}{l}\text { Siswa belum dapat menjawab } \\
\text { pertanyaan yang diberikan,dan } \\
\text { beberapa menjawabnya dengan pasif. } \\
\text { Serta belum memahami konsep dari } \\
\text { materi yang diberikan }\end{array}$ & Kurang baik \\
\hline
\end{tabular}

Dari data yang dilihat pada tabel diatas, yakni melalui tes wawancara yang telah dilakukan dari 25 siswa terdapat 19 siswa yang dapat menjawab pertanyaan atau tes wawancara dengan baik dan benar. Dimana rata-rata jawaban mereka dari 19 yang menjawab dengan benar dan baik yakni mereka dapat menyelesaikan tes wawancara mengenai materi pertumbuhan kacang hijau tersebut dengan menjawab dengan bermacam-macam solusi dan jawaban serta siswa dapat memecahkan masalah dalam satu cara, kemudian dengan menggunakan cara lain salah satunya mereka katakan bahwa bukan hanya mendengarkan materi atau penjelasan dari guru saja pada saat dikelas, namun mereka juga melakukan dengan cara percobaan atau eksperimen yang menunjukan atau membuktikan dari teori yang ada. Dimana dari jawaban mereka setelah mereka melakukan percobaan tersebut mereka dapat melihat langsung, memahami serta mengamati sendiri, hal tersebutlah yang membuat mereka lebih paham mengenai konsep materi yang dijelaskan didalam sebuah teori atau buku serta pengajaran yang telah mereka dapatkan selama dikelas. Bahwa dengan melakukan hal tersebut mereka akan memahmi konsep dari materi IPA yang diajarkan, serta mereka dapat mengembangkan daya pikir mereka mengenai percobaan tersebut sehingga mereka dapat menyelesaikan suatu masalah yaitu bagaimana mereka berpikir agar pecobaan tersebut dapat berhasil melalui metode menyelesaikan dengan pikiran yang kreatif. Selain itu mereka juga menyatakkan dengan melakukan diskusi juga dapat membantu siswa dalam melakukan pembelajaran, yakni mereka mengatakan dengan dilakukannya diskusi mereka akan dapat bertukar fikiran dan bertukar ilmu pengetahuan atau informasi- 
informasi mengenai pengetahuan yang telah mereka dapatkan. Dengan adanya diskusi mereka akan saling menuangkan ide dan saling mengajarakan satu sama lain sehingga mereka juga akan memahami materi yang mungkin belum mereka pahami. Mereka mengatakan bahwa melalui metode diskusi metode tersebut dapat digunakan untuk menerapkan strategi pembelajaran berupapemecahan masalah, yang mana strategi ini diharapkan dapat membuat siswa dapat meningkatkan kemampuan berpikir ilmiah serta dapat mengembangkan pengetahuan siswa sehingga siswa tersebut dapat memahami konsep dari materi tersebut dan dapat menerapkannya. Sedangkan untuk 6 siswa lainnya yang tidak dapat menjawab pertanyaan dengan benar, yakni pada saat saya bertanya mengenai pertanyaan tersebut para siswa itu tidak dapat menjawab, mereka hanya diam dan beberapa lainnya menjawabnya dengan hanya mendengarkan penjelasan dari guru. Ketika saya menenyakan beberapa pertanyaan bagaimana cara mereka untuk menyelesaikan suatu permasalahan, mereka tidak dapat menjawabnya. Bahkan ketika saya menanyakan cita-cita mereka bahkan mereka tidak tahu apa cita-cita mereka. Mereka sangat pasif daya fikir kreatif mereka serta pemahaman konsep mereka masih kurang. Hal ini sangatlah berpengaruh sekali bagi diri mereka untuk masa yang mendatang, sehingga guru harus lebih membrikan motivasi serta pemahaman dan pengajaran yang lebih giat kepada mereka.

Dari hasil penelitian yang telah dilakukan dengan melihat hasil melalui tabel tersebut, dapat dinyatakan bahwasanya 70\% dari siswa SMP Negeri 3 Rambipuji dalam hal berfikir kreatif dan pemahaman konsepnya sudah baik. Dan dapat dinyatakan bahwasanya penerapan model pembelajaran IPA dengan menggunakan metode keterampilan berfikir kreatif siswa dan pemahaman konsep IPA sangat penting dan berpengaruh dalam kegiatan pembelajaran. Karna apabila seorang siswa menerapkan metode tersebut maka siswa akan lebih mudah untuk menguasai materi pembelajaran baik itu melalui daya pikir yang kreatif dan juga paham mengenai konsep dari materi yang diajarkan, karna dalam suatu pembelajaran siswa harus memahami konsep dari materi tersebut misalkan melalui eksperimen bukan hanya teori saja, hal tersebut akan membantu siswa agar dapat mengembangkan semua potensi atau kemampuan yang ada pada dirinya supaya memperoleh pemahaman serta pengetahuan-pengetahuan baru, serta siswa sebagai generasi penerus bangsa harrus memiliki daya fikir kreatifitas yang tinggi agar dapat menyelesaikan suatu permasalahan serta menjadi pemuda generasi bangsa yang kritis untuk masa mendatang agar tidak tersaing dengan negara asing lainya. Karena pendidikan merupakan suatu hal yang memegang peranan sangat penting dalam mempersiapkan sumber daya manusia yang berkualitas agar manusia kedepannya mampu untuk berkompetisi dan bersing dalam menghadapi perkembangan ilmu pengetahuan dan teknologi. Pendidikan yang sudah menggunakan metode yang optimal maka hal tersebut akan sangat membantu siswa dalam mempelajari suatu materi, dengan metode yang tepat.

Dalam suatu proses pembelajaran penerapan model pembelajaran dengan metode berfikir kreatif dan pemahaman konsep siswa harus terus diasah atau. Pembelajaran Ilmu Pengetahuan Alam (IPA) menerapkan suatu pembelajaran yang lebih menekankan pada pemberian suatu pengalaman langsung dengan alam sekitar serta mendorong peserta didik untuk aktif serta mempunyai rasa ingin tahu. Dengan demikian, proses pembelajaran IPA adalah kegiatan penemuan terhadap suatu permasalahan alam disekitarnya atau biasanya disebut dengan istilah pendekatan ilmiah (scientific approach). Pendekatan ilmiah dalam suatu pembelajaran itu sendiri meliputi mengamati, menanya, mencoba, mengolah, dan menyajikan, sehingga setalah dilakukan hal tersebut siswa dapat menyelesaikan suatu permasalahan dengan menggunakan ide kreatifnya dan juga siswa 
akan lebih memahami mengenai konsep dalam materi tersebut, yakni dapat melalui eksperimen ataupun diskusi sehingga pemikiran mereka dapat berkembang. Selain itu didalam materi IPA kita harus mengembangkan kemampuan untuk berpikir logis, kritis, analitis, dan sistematis, karena hal ini berkaitan dengan sifat serta karakteristik keilmuan sains. Namun, fokus dan perhatian menjadi upaya untuk meningkatkan kemampuan berpikir kreatif dalam sains (IPA). Dalam hal ini Berpikir kreatif dan pemahaman konsep merupakan pola pikir siswa yang dapat menghasilkan banyak ide bervariasi.

\section{SIMPULAN}

Dari hasil penelitian yang telah dilakukan dengan melihat hasil melalui tabel data penelitian, dapat dinyatakan bahwasanya 70\% dari siswa SMP Negeri 3 Rambipuji dalam hal berfikir kreatif dan pemahaman konsepnya sudah baik. Dimana dari 25 siswa yang di tes melalui tes wawancara mengenai materi IPA dengan tujuan mengetahui metode berfikir kreatif siswa dan metode pemahaman konsep IPA terdapat 19 siswa yang dapat menjawab pertanyaan atau tes wawancara dengan baik dan benar, dan 6 siswa lainnya belum dapat menjawab tes dengan benar. Dari penelitian yang dilakukan dapat dinyatakan bahwasanya penerapan model pembelajaran IPA dengan menggunakan metode keterampilan berfikir kreatif siswa dan pemahaman konsep IPA sangat penting dan berpengaruh dalam kegiatan pembelajaran.

\section{SARAN}

Berdasarkan hasil penelitian yang dilakukan diharapkan seluruh sekolah untuk menerapkan metode berfikir kreatif serta metode pemahaman konsep kepada para siswa, metode tersebut misalnya dilakukan eksperimen dan diskusi guna meningkatkan nilai akademik siswa tersebut, selain itu dilakukannya penerapan metode-metode tersebut sangatlah berpengaruh baik bagi proses pembelajaran.

\section{DAFTAR PUSTAKA}

Berinkuiri Siswa Melalui Pemanfaatan Bahan Ajar Bernuansa Literasi Sains Dalam Model Pembelajaran Ipa Terpadu. Jurnal BIOSFER, J.Bio. \& Pend.Bio. 1(4): 145-152.

Dahar, R. 2006. Strategi Pembelajaran. Bandung: PT. Remaja Rosdakarya.

Dalam Meningkatkan Pemahaman Konsep Energi Panas Pada Siswa. Jurnal Kreatif Tadulako Online. 4(1): 199215. dan Berpikir Kreatif. Disampaikan pada Konferensi Nasional Matematika (KNM) XIV Universitas Sriwijaya Palembang. Palembang: Universitas Sriwijaya Palembang.

Dan Hasil Belajar Siswa Melalui Penerapan Strategi Guided Inquiry Di SMP Negeri 5 Surakarta Kelas VII F Tahun Pelajaran 2011/2012. Jurnal BIO PEDAGOGI. 1(1): 36-45.

Djamarah, S. B. (1995). Strategi Belajar Mengajar. Jakarta: Rieneka Cipta.

Hendriana, H., \& Sumarmo, U. (2014). Mengukur Kemampuan Berpikir Kreatif. Jakarta: PT. Gramedia.

Mahmudi, A. (2008). Pemecahan Masalah dan Berpikir Kreatif Pemecahan Masalah

Mariana, A. R Dan Praginda, W. 2009. Hakikat IPA Dan Pendidikan IPA. Jakarta: Matematis. Bandung: Refrika Aditama.

Munandar, S. C. Utami. (2009). Mengembangkan Bakat dan Kreativitas Anak Sekolah. Nomor 22 Tahun 2006 Tentang Standar Isi untuk Satuan Pendidikan Dasar dan Menengah. Jakarta: Permendiknas.

Penyelesaian Soal Open-Ended materi Statistika Pada Kelas IX SMP. Jurnal formatif. 7(1): 40-48. 
Permendiknas. 2006. Peraturan Menteri Pendidikan Nasional Republik Indonesia Pusat Pengembangan Dan Pemberdayaan Pendidik Dan Tenaga Kependidikan Ilmu Pengetahuan Alam (PPPPTK IPA).

Rismawati., Ratman., Dan Andi, Imrah., D. 2010. Penerapan Metode Eksperimen

Rizal, M. 2014. Pengaruh Pembelajaran Inkuri Terbimbing Dengan Multi Epresentasi
Salim, Abdul., Zubaidah., Hamdani. 2014. Kemampuan Berpikir Kreatif Siswa Dalam Saputra, A., Widoretno, S., Santosa, S. 2012. Peningkatan Keterampilan Proses Sains Terhadap Keterampilan Proses Sains Dan Penguasaan Konsep IPA Siswa SMP. Jurnal Pendidikan Sains. 2(3): Hal 159-165.

Toharudin., Uus. 2016. Meningkatkan Pemahaman Konsep Ipa Dan Keterampilan 